\title{
A Comparative Analysis of the Brazilian Bioethanol Sector and
}

\section{the Malaysian Palm Biofuel Sector}

\author{
Er, A.C. \\ School of Social, Development and Environmental Studies \\ Faculty of Social Sciences and Humanities, Universiti Kebangsaan Malaysia \\ 43600 Bangi, Selangor Darul Ehsan, Malaysia \\ Tel: 60-3-8921-3945_E-mail: eveer@ukm.my, erahchoy@yahoo.com
}

The research is financed by Centre for Research and Innovation Management, Universiti Kebangsaan Malaysia.

\begin{abstract}
The aim of this paper is to carry out a comparative analysis of the Brazilian bioethanol sector and the Malaysian palm biofuel sector. The major findings for the Brazilian experience are economic nationalism, mandatory policy with initial focus on the domestic market, a nationwide biofuel infrastructure, incentivized mill construction and the adoption of flex-fuel vehicles are the cornerstone of its success. Production factors like abundant sugar cane feedstock and evolving production technologies have made immense contribution. The Malaysian experience however differs from that of Brazil's. The minuscule domestic market, a lack of biofuel infrastructure on a nationwide basis and a small number of diesel passenger vehicles force the Malaysian biofuel producers to be reliant on the international market. The viability of palm biofuel is very much dependent on petroleum prices. If food value is higher than fuel value, palm oil would be diverted towards food production and vice versa.
\end{abstract}

Keywords: Bioethanol, Palm biofuel, Biofuel infrastructure, Flex-fuel vehicles, Food value, Fuel value

\section{Introduction}

The Brazilian biofuel sector has nearly four decades of experience whereas the Malaysian palm biofuel's is a nascent one. In this context, differences are bound to arise due to a host of factors. The Brazilian biofuel sector can be classified as a "success story" due to its sustainability despite the challenges faced by it. The Malaysian palm biofuel sector is in the introductory phase of the industry lifecycle and would encounter the throes of growth. The aim of this paper is to study the development of each respective nation's biofuel sector, its successes and challenges, and lessons that can be learned. By studying the development of each nation's biofuel sector, a comparative analysis can be carried out. The main foci in this paper are government policy, biofuel infrastructure, market forces, and factors of production. By understanding these main forces at play, an in-depth comparative analysis can be carried out for the biofuel sector in both countries.

\section{Literature Review}

Political modernization is crucial in ecological restructuring (Mol, 1995). Political modernization encompasses the transformation in the role of the state in relation to policy formulation and also cooperation between government and industry. The role of the state in ecological restructuring is pertinent to the palm oil production chain in Malaysia in relation to policy formulation and the increasing importance of market dynamics and economic agents (Er, 2007).

Later researches in China also validate this claim. The infancy of wind-power renewable energy in China requires policy support and market cultivation. Policy support has effectively reduced the cost of wind-power installed capacity, stimulated the localization of wind-power manufacture and driven investment in wind-power (Wang, 2010). This is also true for power generation in China. Renewable energy developments are found to be strongly correlated with the promulgation of relevant policies (Zhao, et al., 2011). However, in contrast, the development of liquid biofuel in Russia has stagnated due to low policy and institutional priority accorded to non-fossil fuel exploitation and lack of market opportunities (Pristupa, et al., 2010).

The food versus fuel debate has impacted on biofuel. It has been argued that the conversion of food into fuel would intensify the problem of global under-nourishment. In addition, this has also drawn a lot of criticisms 
especially from environmental non-governmental organizations. The development of biofuel is often related to deforestation of rainforests and loss of biodiversity. The palm biofuel sector in Malaysia is also caught in this environmental debate (Er, 2010; Zhou et al., 2009). This is despite the fact that oil palm is an energy-efficient crop (Er, 2010; Lam, et al., 2008). Likewise, the rapid expansion of agriculture in Brazil is often linked to deforestation, loss of biodiversity and social conflicts (Cunningham and Cunningham, 2008). It is claimed that the expansion of sugar cane production for bioethanol has adverse environmental consequences.

\section{Research Methods}

The research methods adopted are based on a country basis, taking into consideration the resources at hand. For Malaysia, a combination of two methods is applied. The first method is via an in-depth interview with an open-ended questionnaire focusing on key informants that are knowledgeable about palm biofuel in Malaysia in particular and biofuel in general. This is complemented and supplemented by content analysis. For Brazil, the primary research method is content analysis. Content analysis is chosen for both Malaysia and Brazil as social phenomena can be deciphered and delineated through written or textual constituents. Content analysis provides the platform for conceptual and relational analysis.

\section{The Brazilian Bioethanol Sector}

The industrial take-off of bioethanol production occurred in the late seventies with the introduction of the National Fuel Alcohol Programme (Proálcool) by the Brazilian government in response to the spiraling oil prices in the seventies. The backdrop for this programme was that Brazil imported four-fifths of its oil needs and was also a large debtor nation. The aim of Proálcool is to substitute petrol with bioethanol by making sugarcane as the main feedstock (ISIS Report 18/12/06). This programme also included distillery construction with state support, tax-incentivised bioethanol-powered cars, and a massive expansion of bioethanol fuel pump infrastructure. The drop in petroleum prices in the eighties and nineties led to an acute shortage of bioethanol supply. This destroyed public confidence in bioethanol as Brazilian drivers could not find fuel. When petroleum prices rebounded, car manufacturers introduced flex-fuel vehicles powered by any mixture of petrol and bioethanol, thus providing the driver with a fuel choice which is cheaper or easily available. Motorists today can choose from 100 percent bioethanol, petrol blended with 20-25 percent bioethanol or fossil fuels. In the current scenario of higher petroleum prices, the demand for both bioethanol powered cars and flexi-fuel cars have escalated (www.ifuel.nl/brazil.pdf).

Bioethanol production cost has decreased over the years as growing and production technologies have improved. The sugar extraction yield has increased from $88 \%$ in 1975 to $96 \%$ in 2006 whereas average fermentation yield increased from $75 \%$ to $90 \%$ for the same period. Likewise, average bioethanol productivity increased from 3200 litres per hectare in 1975 to 7500 litres per hectare in 2006. As at November 2007, the price of bioethanol, known as alcohol in Brazil, was 51.4 Eurocent per litre as compared to 71.5 Eurocent per litre for diesel (Dörfler, 2008).

78 percent of the approximately 350 mills in Brazil can produce both bioethanol and sugar. 15 percent produce solely bioethanol and the remaining only sugar. The Brazilian bioethanol sector has attracted foreign direct investment due to the low production cost (Frost and Sullivan Market Insight 22 May 2007). This is also in tandem with the transition to renewable energy. The robust Brazilian bioethanol sector is mainly due to the abundance of sugar cane feedstock. The expansion in bioethanol production not only caters to the domestic but also the export market. Bioethanol production in 2007 amounted to 21 billion litres and is forecasted to grow to 28 billion litres in 2012 with the expansion in global biofuel demand (Dörfler, 2008). Even though Brazil has vast tracts of land, the expansion of sugarcane cultivation also faces environmental concerns like deforestation and in tandem loss of biodiversity, intensive use of agrochemicals and air pollution as a result of burning the cane and field to facilitate harvesting (Ortiz, 2006; Barber, Pellow and Pereira, 2008). This expansion will also push soybean, rice, corn and pasture into the more marginal areas and towards and onto the Amazon forest areas (Time Magazine, 28 April 2008).

\section{The Malaysian Palm Biofuel Sector}

The search for palm biodiesel started in 1982, gained traction and culminated in the launch of the National Biofuel Policy in 2006. (Ministry of Plantation Industries and Commodities, 2005, 2006). This policy's primary aim is to reduce dependence on fossil fuel and promote the demand for biofuel for transport, manufacturing and export, as well as a price stabilization mechanism in mopping up excess supply of palm oil. Through indigenous technologies, palm methyl esters and the B5 blend of 5 percent processed liquid palm oil and 95 percent petroleum diesel were developed as a suitable fuel for the transportation and industrial sector. The next step in the sector's take-off phase is the enactment of the Biofuel Industry Act 2007 (Malaysian Biofuel Industry Act 
2007). This Act basically outlines the licensing requirements and as the name implies, biofuel is the primary focus without any element of switchability to other main outputs. The by-products are glycerine and photonutrients like vitamin $\mathrm{E}$ and carotene (Hoh 2009). If other main outputs like oleochemicals were to be produced, a new license would be required. Together with tax incentives offered for the construction of the biodiesel plant, 91 licenses were granted by the government till December 2008 with a total capacity of 10.2 million tonnes. At this juncture, only 16 plants were built but most were not operating due to low prices of biofuel in the later part of 2008 and early 2009 (Agence France-Presse 12 March 2009).

Following the launch of the National Biofuel Policy, the Malaysian government stated that the B5 biodiesel programme would be implemented in the domestic market by 2010 (Kamar Nor Aini Bt Kamarul Zaman, 2009). However, this was postponed to a later date. The B5 is touted to be even better than petroleum diesel as it has lower emission and can be used without any vehicular modification. However, the proposed mandatory blend is put on hold due to a variety of factors. It is reported that the major oil companies are reluctant to expedite the add-on biodiesel infrastructure on the existing fuel infrastructure due mainly to infrastructure costs like blending facilities and pump network, logistical constraints like the need to transport palm methyl esters from factory to a blending depot and pricing. The subsidized retail petroleum diesel and RON 95 together with the increase in crude palm oil prices due to tightness of vegetable oil supply made the B5 untenable to a large majority of Malaysian drivers as the fuel of choice. In addition, it is estimated that about 5 percent of the Malaysian motor vehicle population are diesel vehicles (Hoh 2009). As there is no mass domestic demand and the biodiesel infrastructure not in place yet, the only avenue opened to the palm biodiesel producers would be the international biofuel market.

As Malaysian palm biodiesel is primarily for the export market, it has to contend with the vagaries in the international market place. The viability of Malaysian palm biofuel in the international biofuel market is dependent on five key factors: fossil fuel price, crude palm oil price, tax subsidy provision by developed countries, US Dollar versus Ringgit Malaysia conversion rate as biofuel is traded in US Dollar, and margins for Malaysian biofuel producers. For 2008, the export of 182,108 tonnes of biodiesel as compared to the overall export of 20,979,200 tonnes of palm oil products constitutes a meager 0.9 percent (MPOB Online 2009a, 2009b).

Like in the case of Brazil, the expansion of oil palm cultivation is linked to environmental issues. Deforestation, destruction of peatlands and loss of biodiversity are the major environmental issues faced by the oil palm and palm oil sector. Western environmental non-governmental organizations claimed that the expansion of the palm biofuel market would lead to further encroachment of the rainforests and peatlands.

\section{Comparative Analysis of Brazilian Bioethanol Sector and Malaysian Palm Biofuel Sector}

Market creation via a mandatory biofuel programme in Brazil is a response to an economic emergency. Savings from the importation of fossil fuel would help to lighten the debt burden of the country. This is in direct contrast to the Malaysian scenario as there is much less urgency as Malaysia is a net petroleum exporting country. The move towards palm biofuel is a measured deliberate process to mop up excess supply of palm oil and the development of the renewable energy sector is part of the country's energy diversification strategy. Malaysia does not have the strong push factor as experienced by Brazil. As market creation in the domestic Malaysian palm biofuel is not in place yet, the export-centric nature of palm biofuel is influenced by both push and pull factor. The push factor is due to lack of domestic demand whereas the pull factor is mainly due to demand emanating from developed countries in fulfilling mandatory renewable energy requirements.

The Brazilian mandatory biofuel programme under dire economic circumstances pushed the country towards establishing the requisite bioethanol infrastructure. The learning and experience curve was amplified in the eighties and nineties with the drastic drop in petroleum prices leading to the adoption of flex-fuel vehicles. In the context of Malaysia, market forces, especially the international market, dictate the viability of the palm biofuel sector. If palm biofuel is profitable, the plants would ramp up production and if otherwise, there would be a plant shutdown as palm oil would be diverted to the food sector. If the fuel value is higher than the food value, palm oil would be channeled as feedstock to the palm biofuel plants and vice versa.

The factors of production have in no small measure aided the development of the Brazilian bioethanol sector. Sugarcane cultivation was started in the sixteenth century and is a highly productive crop in Brazil. Brazil is also blessed with a large land mass which allows for the expansion in sugarcane cultivation despite environmental criticisms. This leads to an abundant and relatively cheap feedstock for the bioethanol sector. Malaysia does not have the comparative advantage of land like Brazil and likewise, the expansion of oil palm cultivation is greeted with protestation by environmental non-governmental organizations. Developing economies like China with high economic growth have imported large quantities of palm oil and this has contributed to some measure of 
tightness in the vegetable oil market. In essence, vegetable oil, inclusive of palm oil, would not be very cheap in the foreseeable future. Another comparative advantage enjoyed by the Brazilian bioethanol sector is the production model of flexible manufacturing system. If bioethanol is not profitable, the feedstock can be diverted to the production of sugar and vice versa. As in the case for Malaysia, the palm biofuel plant is licensed to produce one main product (with the exception of by-products) and thus offers a magnitude of inflexibility. If demand and pricing is not to the advantage of a palm biofuel producer lacking a deep pocket, the only option is a plant shutdown.

The genesis and development of the bioethanol sector in Brazil was built on the domestic front and the intense domestic competition forces the bioethanol producers and retailers to be competitive and efficient. The large domestic market together with an existing biofuel infrastructure and flex-fuel vehicles create the conditions for economies of scale. The expansion to overseas markets rides on the existing prevailing conditions in Brazil. The nascent palm biofuel sector in Malaysia is export centric and is dependent on the vagaries of international demand. The varying demand from the overseas market does not create the conditions for economies of scale.

\section{Conclusion}

The scape for the Brazilian bioethanol sector and the Malaysian palm biofuel sector differs greatly. The longer experience and learning curve undergone by the Brazilian bioethanol sector has worked to its advantage. Economic nationalism underpinned by a mandatory policy provided the structural platform for the Brazilian bioethanol sector to grow. The construction of a bioethanol infrastructure and the majority of mills adopting a flexible manufacturing system help to firm up the supply equation. This is supported in no small measure by production factors like abundant sugar cane feedstock and evolving growing and production technologies. Production factors like mills, sugar cane feedstock and production technologies were leveraged on in tapping the international biofuel market. The initial mandatory policy created market demand under dire economic circumstances in the seventies. The introduction of flex-fuel vehicles gave customers a fuel choice. The relatively higher prices of petroleum in the first decade of the twenty first century helped to sustain the demand for flex-fuel vehicles and consequently the demand for bioethanol. Sustaining domestic market demand is a crucial element in the survivability and sustainability of the bioethanol sector in Brazil.

The situation, however, is different in Malaysia. From a supply side perspective, the biofuel infrastructure is not ready on a nationwide basis. Even though there is a number of biofuel plants, production is dictated mainly by petroleum prices and international demand. The lack of production switchability is another drawback in terms of production sustainability. The sustainability of palm biofuel is highly dependent on fuel value being higher than food value. If otherwise, palm oil feedstock will be diverted to food production. This is not aided by the minuscule domestic market as it is not able to support the existing plants.

One commonality, however, exists for the biofuel sector in both countries. The criticisms by Western environmental non-governmental organizations are directed at the production of sugar cane feedstock and palm oil feedstock for biofuel. The production of such feedstock will lead to further encroachment and destruction of rainforests and also biodiversity. In addition the European Union's Renewable Energy Directive has a different carbon rating for palm biofuel which works to its disadvantage in terms of price. Malaysia claims that this directive has been used by the European Union as a non-tariff barrier against palm biofuel.

\section{References}

Barber A., Pellow, G. \& Pereira, M.D. A. (2008). The sustainability of brazilian sugarcane bioethanol: A literature review. Prepared for Energy Efficiency and Conservation Authority (EECA), May 2008.

Cunningham, W.P. \& Cunningham, M.A. (2008). Principles of environmental science: Inquiry and applications. ( $4^{\text {th }}$ ed.). New York: McGraw-Hill Companies, Inc., (Chapter 7). ISBN: 978-0-07-110194-3.

Dörfler, J. (2008). The Brazilian bioethanol program - impact and contribution on global biofuel market. Conference, Graz, January $18^{\text {th }}, 2008$.

Downie, A. (2008). Brazil's counterattack on biofuels. Time 28 April 2008. [Online] Available: http://www.time.com/time/world/article/0.85999.1735644.00html (September 26, 2009).

Er, A.C. (2007). A quantitative methodology to test ecological modernization theory in the Malaysian context. $\mathrm{Ph} . D$. Thesis, Wageningen University, The Netherlands. ISBN: 978=90-8504-764-3.

Er, A.C. (2010). The challenges facing the palm biofuel sector in Malaysia. Asian Profile, Vol. 38(4), August 2010, pp. 399-404. ISSBN: 03048675.

Hoh, R. (2009). Malaysia: Biofuels Annual. Annual Report 2009. USDA Foreign Agricultural Service, Global 
Agriculture Information Network.

IFUEL. (2009). [Online] Available: www.ifuel.nl/brazil.pdf (September 19, 2009).

ISIS Report 18/12/06. (2009). Biofuels Republic Brazil. [Online] Available: http://www.i-sid.org.uk/BiofuelRepublicBrazil.php?printing=yes (September 19, 2009).

Kamar Nor Aini Kamarul Zaman. (2009). Challenges await Asian biodiesel producers. The Star Online, 25 March. 2009. [Online] Available: http://palmnew.mpob.gov.my/palmnews/print.php?idnews=5898 (September 2, 2009).

Lam, M.K., Lee, K.T. \& Mohamed, A.R. (2008). Malaysian palm oil: Surviving the food versus fuel dispute for a sustainable future. Renewable and Sustainable Energy Reviews, Vol. 13 (6-7), August-September 2009, pp. 1456-1464. DOI: 10.1016/j. rser.2008.09.009.

Malaysia urged to force big oil to produce biofuel. (2009). Agence France-Presse 12 March 2009. [Online] Available: http://www.climateark.org/shared/reader/welcome.aspx?linkid=121261 (March 13, 2009).

Malaysia, Ministry of Plantation Industries and Commodities. (2005). Palm biofuel and palm biodiesel fuels for the future. Kuala Lumpur:Malaysian Palm Oil Board.

Malaysia, Ministry of Plantation Industries and Commodities. (2006). The national biofuel policy. 21 March.

Malaysian Biofuel Industry Act 2007. (2009). [Online] Available: http://www.digitalibrary.my/index.php?view=article \&catid=72\%3Aacts-a-bills\&id=845\%3Amalaysian-biofuel-i ndustry-act-2007\&option=com_content\&Itemid=25 (September 28, 2009).

Malaysian Palm Oil Board Online. (2009a). Summary of the Malaysian oil palm industry 2008. [Online] Available: http://econ.mpob.gov.my/stat/web_report1.php?val200884 (June 9, 2009).

Malaysian Palm Oil Board Online. (2009b). Summary of the Malaysian oil palm industry 2009. [Online] Available: http://econ.mpob.gov.my/stat/web_report1.php?val200984 (June 9, 2009).

Mol, A.P.J. (1995). The refinement of production: Ecological modernization theory and the chemical industry. Utrecht: Jan van Arkel/International Books.

New entrants to the Brazilian bioethanol industry. (2007). Frost and Sullivan Market Insight 22 May 2007.

Ortiz, L. (2006). Sustainability issues of bioethanol from Brazil. October 16, Amsterdam.

Pristupa, A.O., Mol, A.P.J. \& Oosterveer, P. (2010). Stagnating liquid biofuel, developments in Russia: Present status and future perspectives. Energy Policy, Vol. 38 (7), July 2010, pp. 3320-3328. DOI: 10.1016/j. enpol.2010.02.003.

Wang, Q. (2010). Effective policies for renewable energy: The example of China's wind-power: Lessons for China's photovoltaic power. Renewable and Sustainable Energy Reviews, Vol. 14(2), February, pp. 702-712. DOI: 10.1016/j.rser.2009.08.013

Zhao, Z.Y., Zuo, J., Fan, L.L. \& Zillante, G. (2011). Impacts of renewable energy regulations on the structure of power generation in China - A Critical Analysis. Renewable Energy, Vol. 36(1), January 2011, pp. 24-30. DOI: 10.1016/j.renene.2010.05.015

Zhou, A. \& Thompson, E. (2009). The development of biofuels in Asia. Applied Energy, Vol. 86 (Supplement 1), November 2009, pp. S11-S20. DOI: 10.1016/j.apenergy.2009.04.028. 